\title{
Juan Valverde de Amusco (1525-1588): who was the great anatomist of the Renaissance
}

\author{
IIlhan Bahşi ${ }^{1}$ • Zeynep Simgül Büyükbeşe ${ }^{2}$ • Saliha Seda Adanir ${ }^{1}$
}

Published online: 23 April 2020

(C) Springer-Verlag GmbH Germany, part of Springer Nature 2020

\section{His life}

Spanish physician and anatomist Juan Valverde de Amusco (or "de Hamusco") (Ioannis Valuerdi Muscensis) (1525-1588) (Fig. 1) was born in an old village in Palencia which is a province in CastillaLeón autonomous community in Northern Spain [1, 2]. Markatos et al. [1] stated that Valverde's biographical details are insufficient and conflicting which opposes to his reputation in anatomy. He went to Italy around 1542 where he spent most of his educational and professional life $[1,3]$.

He studied medicine in Padua and Rome under Realdo Columbo (1516-1599) who succeeded Andreas Vesalius as the chair of anatomy of Padua and Bartolomeo Eustachi (1513-1574) who is an admirable anatomist as later understood $[1,2,4]$.

Saliha Seda Adanir

seda.adnr93@gmail.com

İlhan Bahși

dr.ilhanbahsi@gmail.com

Zeynep Simgül Büyükbeșe

zbuyukbese@gmail.com

1 Department of Anatomy, Faculty of Medicine, Gaziantep University, TR-27310 Gaziantep, Turkey

2 School of Medicine, Gaziantep University, Gaziantep, Turkey

\section{His works}

Valverde published several books on anatomy. His first book "De animi et corporis sanitate tuenda libellus" was published in 1522, Paris. This book was about hygiene and health [3]. Valverde's most known work "Historia de la composicion del cuerpo humano" (A history of the composition of the human body) was first published in 1556, Rome (Fig. 2, Fig. 3 and Cover) [1], and it is thought to be the most commonly read text in Europe in sixteenth century as López-Valverde et al. stated [2].

Valverde's works included experiments done using dogs along with the experiments done using monkeys and pigs traditionally since Galen's era [1]. Thirtyeight out of 42 of the illustrations engraved on copperplates were taken directly from the "De humani corporis fabrica" by Andreas Vesalius [3]. Original illustrations were most probably drawn by Gaspar Becerra (1520-1568) and engraved on copperplates by Nicolas Beatrizet (1507-1570) [3].

Choulant and Streeter [5] stated that he created his Spanish manual of anatomy without doing much dissecting; in fact, he himself says that he merely copied Vesalius' figures, although there were also drawings which cannot be seen in Vesalius' works. Likewise, Markatos et al. [1] stated that there were times when Valverde corrected Vesalius' illustrations such as muscles of the eyes, nose, and larynx. Valverde's works were republished entirely or in parts 16 times in 4 
Fig. 1 Juan Valverde de Amusco (1525-1588), which can be found at https://es.wikipedia.org/wiki/ Juan Valverde de Amusco\#/ media/File:Juan_Valverde_de Hamusco._Line_engraving_by_ N. Beatrizet, $1 \overline{5}$ Wellcome V0005974.jpg. Accessed 08 March 2019

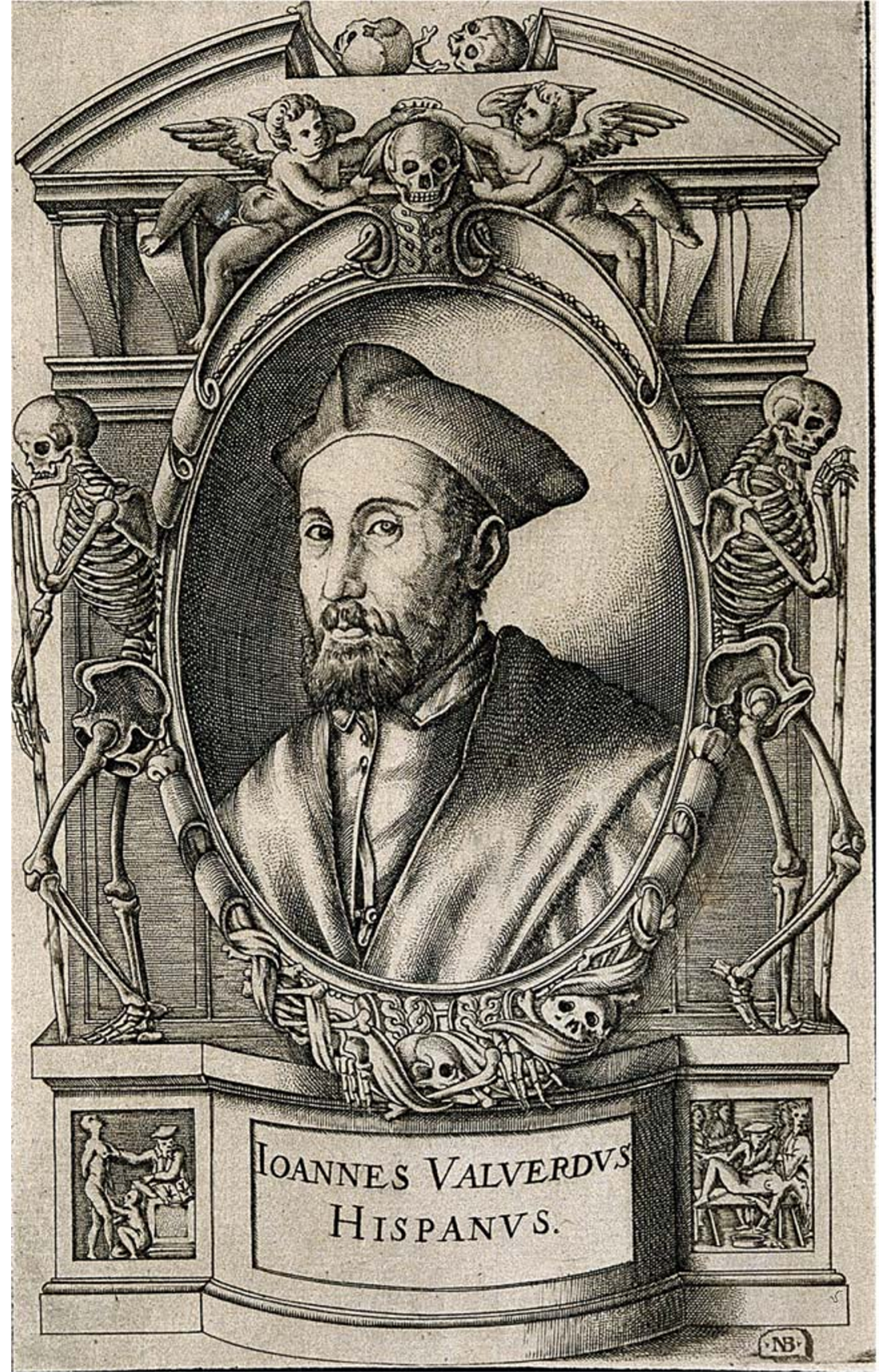

López-Valverde et al. [2] stated that Valverde's terminology, clarity of his detailed depictions, and exposition added to comparative anatomy and occasionally given therapeutic languages (Spanish, Dutch, Italian, and Latin) in a period of time which was slightly longer than a century [2]. 
Fig. 2 Title page of Historia de la composicion del cuerpo humano and some drawings in this book
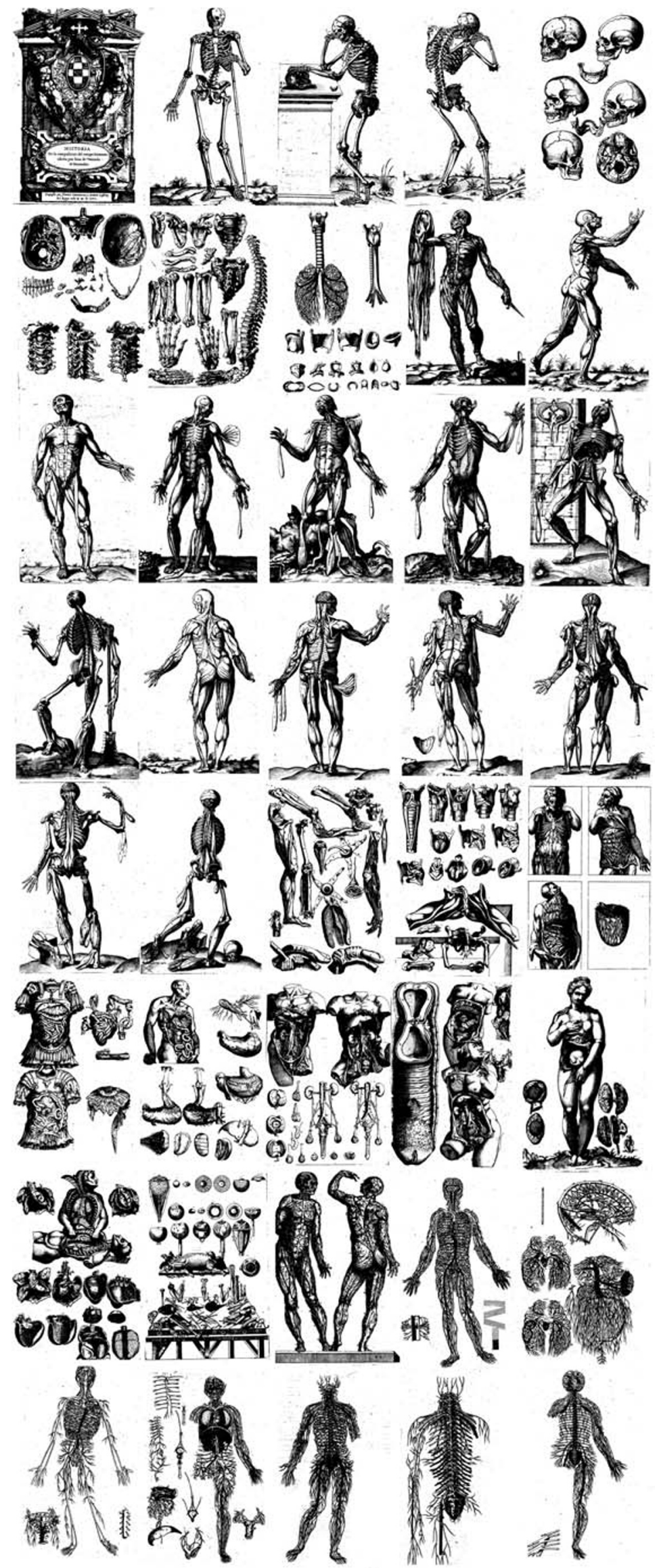


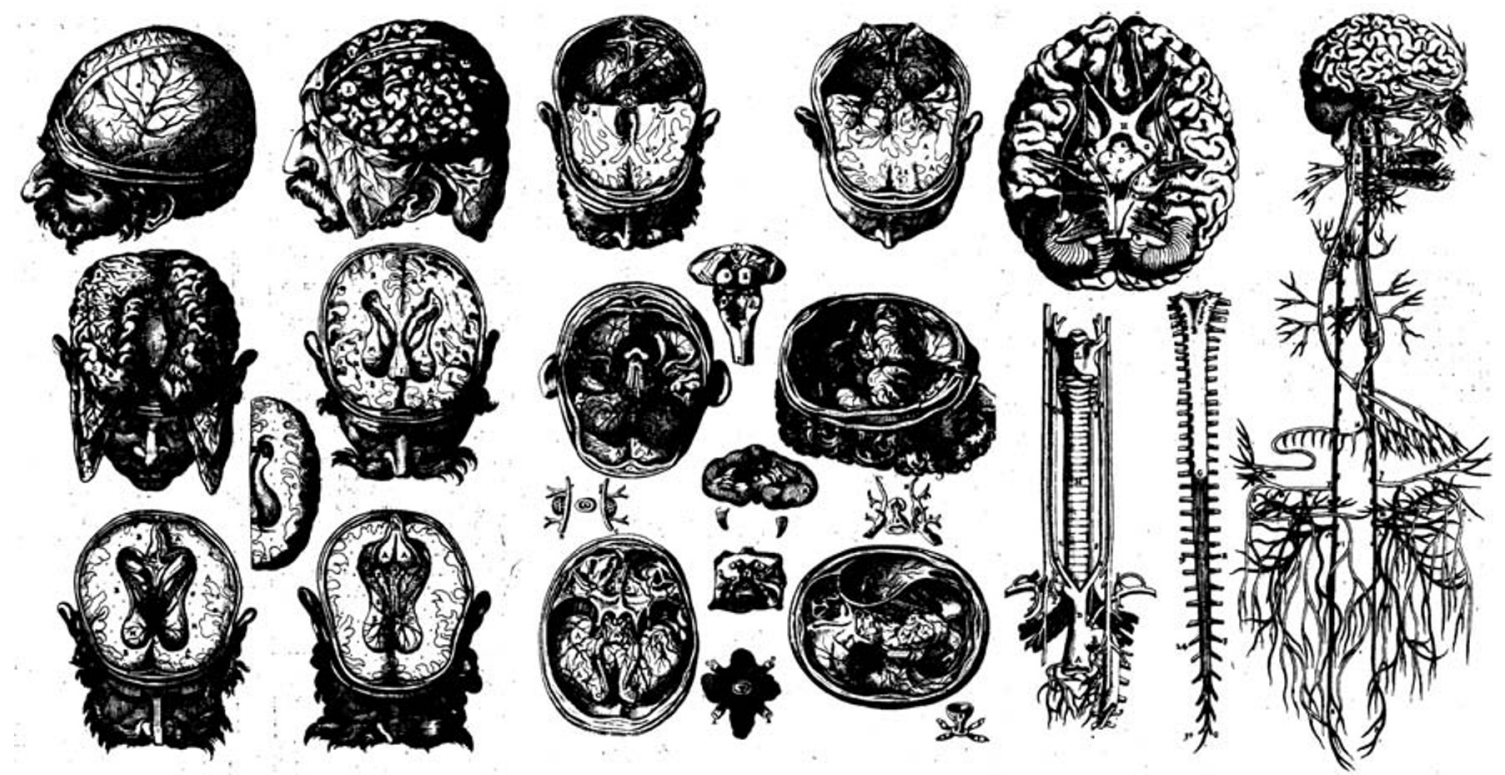

Fig. 3 and Cover The drawings of the nervous system in the book named Historia de la composicion del cuerpo humano

recommendations signifies the importance of his work as an anatomical-historical document. Besides, Valverde is accepted to be the most important Spanish anatomist of the Renaissance [3].

\section{Conclusion}

Although it is stated that he plagiarized Vesalius' works by some authors, it is seen that Valverde has made contributions and arrangements which made Vesalius' works accessible for more people. Therefore, Valverde must be appreciated.

\section{Compliance with ethical standards}

Conflict of interest None.

\section{References}

1. Markatos K, Arkoudi K, Androutsos G (2017) Juan Valverde de Amusco (1525-1588): an eminent anatomist of the renaissance or a plagiarist of Vesalius? His work and its impact in renaissance anatomy. Acta Chir Belg 117:407-411

2. López-Valverde A, De Diego RG, De Vicente J (2013) Oral anatomy in the sixteenth century: Juan Valverde de Amusco. Br Dent J 215:141-143

3. Historical Anatomies on the Web: Valverde: Author \& Title Description. https://www.nlm.nih.gov/exhibition/ historicalanatomies/valverde bio.html. Accessed 08 March 2019

4. Adanır SS, Bahși İ (2019) The giant anatomist, whose value is later understood: Bartolomeo Eustachi. Childs Nerv Syst. https://doi.org/10.1007/s00381-019-04107-1

5. Choulant L, Streeter EC (1920) History and bibliography of anatomic illustration in its relation to anatomic science and the graphic arts. University of Chicago Press, Chicago

Publisher's note Springer Nature remains neutral with regard to jurisdictional claims in published maps and institutional affiliations. 